\title{
Iuramentum na inaugurację wladzy w mieście średniowiecznym. Przykład Krakowa
}

Iuramentum odgrywało bardzo ważną rolę w stosunkach nie tylko prawnych, ale także społecznych średniowiecznej Polski. Już od czasów najdawniejszych Słowianie praktykowali składanie przysiąg, traktując je przede wszystkim jako dowód swojej prawdomówności. Wszak przysięga miała wówczas charakter klątwy - krzywoprzysięzcę i jego rodzinę miało spotkać nieszczęście ${ }^{1}$.

Literatura dotycząca przyrzeczeń oraz rytuału związanego z ich składaniem jest dość obszerna, jednak wciąż nie omawia tego zagadnienia nazbyt szeroko. Polscy badacze podejmowali najczęściej temat przysiąg sądowych ${ }^{2}$ oraz ich

\footnotetext{
${ }^{1}$ W. Hejnosz, Przysięga, [w:] Stownik starożytności stowiańskich. Encyklopedyczny zarys kultury Stowian od czasów najdawniejszych do schyłku wieku XII, red. G. Labuda, Z. Stieber, t. 4: $P-R$, Wrocław-Warszawa-Kraków 1970, s. 402-403.

${ }^{2}$ Spośród prac traktujących stricte o przysiędze sądowej warto wymienić: S. Borowski, Przysięga dowodowa w procesie polskim późniejszego średniowiecza, Warszawa 1926; W. Nestorowicz, Oskarżony i jego przysięga w rozwoju historycznym procesu karnego, Warszawa 1933; V. Proházka, Przysięga w postępowaniu dowodowym narodów stowiańskich do końca XV w., „Czasopismo Prawno-Historyczne” (dalej: CPH) 12 (1960), nr 1, s. 19-84; B. Lesiński, Przysięga na dusze jako dowód w średniowiecznym prawie polskim, CPH 24 (1972), nr 2, s. 20-36; K. Skrzypczak, Ryt przysięgi sądowej w średniowiecznej Polsce, praca licencjacka obroniona w Instytucie Historii Uniwersytetu Jagiellońskiego w 2014 r. Warto również zwrócić uwagę, że badania przysięgi dowodowej $\mathrm{w}$ procesie ziemskim są ułatwione $\mathrm{z}$ uwagi na istnienie kilku wydawnictw źródłowych: Wielkopolskie roty sądowe XIV-XV wieku, t. I-V, wyd. H. Kowalewicz, W. Kuraszkiewicz, Poznań-Wrocław 1959-1981; Roty przysiag krakowskich z końca wieku XIV, wyd. R. Hube, „Biblioteka Warszawska” 4 (1874), s. 184-211; Nieznane średniowieczne roty przysiag Wareckie z lat 1419-1480, wyd. F. Piekosiński, [w:] Archiwum Komisji Prawniczej, t. 8, cz. 1, Kraków 1907, s. 43-59. Zob. też K. Piekarski, Przeglad wydawnictw średniowiecznych zapisek i rot przysiag sądowych z ksiag grodzkich i ziemskich, Kraków 1919.
} 
szczególnych rodzajów ${ }^{3}$. Istnieje również kilka prac mówiących o samym rytuale czy ceremoniach towarzyszących składaniu przysięgi, również tej, która „inaugurowała władzę", czyli była formą ślubowania ${ }^{4}$.

Wśród wymienionych publikacji trudno jednak wyróżnić te traktujące o przysiędze w średniowiecznym mieście, którego życie toczyło się nieco innym rytmem niż społeczności zamieszkującej extra muros civitatis. W niniejszym opracowaniu postaram się więc nakreślić ten właśnie rodzaj średniowiecznego iuramentum na przykładzie przysiąg funkcjonujących w średniowiecznym Krakowie. Przysięga sądowa zarówno w procesie miejskim, jak i ziemskim miała bardzo podobny charakter, a zatem temat ten posiada już dość szeroką literaturę; celem niniejszego artykułu będzie więc przybliżenie kwestii przysiąg spełniających rolę ślubowania, jakie składali mieszczanie krakowscy w chwili obejmowania urzędu bądź powierzanej im funkcji w wewnętrznym zarządzie gminy.

Roty tych przysiąg zachowały się głównie w kopiariuszach przywilejów i praw miejskich będących pomocami dla pracowników krakowskiej kancelarii miejskiej. Najwięcej z nich pomieszczono w tzw. I kodyfikacji (znanej w literaturze jako Kodeks Grabowskiego lub Najstarszy zbiór), tworzonej systematycznie od lat siedemdziesiątych XIV w. ${ }^{5}$ Znalazło się w niej dwadzieścia osiem tekstów przysiąg miejskich, jednak niektóre z nich zostały wpisane kilkakrotnie, najczęś-

${ }^{3}$ Wśród tych należy wspomnieć o pracach Władysława Semkowicza dotyczących przysięgi na słońce: W. Semkowicz, Przysięga na słońce. Studium porównawcze prawno-etnologiczne, [w:] Księga pamiątkowa ku czci Bolesława Orzechowicza, t. 2, Lwów 1916, s. 304-377; idem, Jeszcze o przysiędze na stońce w Polsce, [w:] Studia historyczne ku czci Stanisława Kutrzeby, t. 1, Kraków 1938, s. 429-444. Zob. także S. Szczotka, Stosowanie przysięgi na słońce w polskim sądownictwie wiejskim w XVIII wieku, CPH 2 (1949), s. 452-458; W. Bukowski, O przysiędze na stońce raz jeszcze. Przysięga w postępowaniu granicznym w księstwie zatorskim w 1529 roku, [w:] Memoria viva. Studia historyczne poświęcone pamięci Izabeli Skierskiej (1967-2014), red. G. Rutkowska, A. Gąsiorowski, Warszawa-Poznań 2015, s. 789-804. O przysiędze żydowskiej zob.: H. Zaremska, Iuramentum Iudaeorum - żydowska przysięga w średniowiecznej Polsce, [w:] E scientia et amicitia. Studia poświęcone Profesorowi Edwardowi Potkowskiemu w sześćdziesięciolecie urodzin i czterdziestolecie pracy naukowej, red. M. Drzewiecki et al., Warszawa - Pułtusk, 1999, s. 229-243. W tychże pracach także dalsza literatura.

${ }^{4}$ B. Wyrozumska, Obyczaj średniowiecznej sali sądowej, „Zeszyty Naukowe Uniwersytetu Jagiellońskiego" 663 (1985), Prace Historyczne, z. 74, s. 89-95; Z. Dalewski, Władza - przestrzeń - ceremoniat. Miejsce i uroczystość inauguracji władcy w Polsce średniowiecznej do końca XIV w., Warszawa 1996; A. van Gennep, Obrzędy przejścia. Systematyczne studium ceremonii, thum. B. Biały, Warszawa 2006; G. Althoff, Potęga rytuału. Symbolika władzy w średniowieczu, thum. A. Gadzała, Warszawa 2011; M. Duda, S. Jóźwiak, Ze świata średniowiecznej symboliki. Gest i forma przysięi w chrześcijańskiej Europie ( $X$-XV w.), Kraków 2014.

${ }^{5}$ Najstarszy zbiór przywilejów i wilkierzy miasta Krakowa, wyd. S. Estreicher, Kraków 1936 (Wydawnictwa Komisji Historycznej Polskiej Akademii Umiejętności, 82), s. XIII-XV; B. Wyrozumska, Kancelaria miasta Krakowa w średniowieczu, Kraków 1995, s. 54. 
ciej w różnych formach ${ }^{6}$. Z tego kopiarza $\mathrm{w}$ dużej mierze korzystano jeszcze na początku XVI w. podczas sporządzania nowego zbioru praw, znanego dziś jako Kodeks Baltazara Behema. W tym kodeksie, kojarzonym dziś głównie ze zdobiącym go cyklem miniatur przestawiających rzemieślników i ich herby, znalazło się szesnaście przysiąg (w tym jedna późnonowożytna, wyłączona z niniejszych rozważań) ${ }^{7}$. Pojedyncze przysięgi można znaleźć również w kilku księgach miejskich $^{8}$, lecz te najpewniej znalazły się tam akcydentalnie, wpisane przez bardziej skrupulatnego pisarza notującego nowo obrane osoby mające sprawować pewne funkcje w środowisku miejskim.

Poza wspomnianymi rotami, które omówię w dalszej części tekstu, w tych dwóch kopiarzach notowano także przysięgi homagialne, jakie przedstawiciele krakowskiej społeczności miejskiej składali kolejnym monarchom - w Kodeksie Grabowskiego dla okresu średniowiecza, w Kodeksie Behema niestety tylko te z okresu nowożytnego (od Władysława IV do Stanisława Augusta Poniatowskiego) $)^{9}$. Zarówno kolejni władcy, jak i sama społeczność miejska bez wątpienia przykładali do nich niebagatelną wagę. Doskonale poświadcza to zachowana w Najstarszym zbiorze relacja z wydarzeń mających miejsce po narodzinach Władysława, syna króla Władysława Jagiełły i Zofii Holszańskiej.

27 lutego 1425 r. monarcha zwrócił się do mieszczan krakowskich z prośbą o złożenie mu przysięgi wierności. Początkowo rajcy niechętnie odnieśli się do tego pomysłu, twierdząc, iż robią to rokrocznie, gdy uzyskują nominację na swoje stanowiska. Pod naciskiem panów koronnych zgodzili się jednak na ponowne ślubowanie, lecz pod warunkiem potwierdzenia przez króla przywilejów miasta Krakowa. Po uzyskaniu tego zapewnienia, na Rynku przed ratuszem miejskim i w obecności dostojników państwowych, rajcy złożyli przysięgę na krzyż trzymany przez biskupa krakowskiego Zbigniewa Oleśnickiego; przedstawiciele pospólstwa również złożyli przysięgę wierności, jednak poprzez uniesienie palców ${ }^{10}$.

${ }^{6}$ Edycję tychże przysiąg zob. Najstarszy zbiór, s. 44-52.

${ }^{7}$ Edycję tych przysiąg zob. Kodeks dyplomatyczny miasta Krakowa (dalej: KDmK), t. II, wyd. F. Piekosiński, Kraków 1882 (Monumenta Medii Aevi Historica Res Gestas Poloniae Ilustrantia [dalej: MMAE], 7), s. 484-488.

${ }^{8}$ Kraków, Archiwum Narodowe (dalej: ANK), rkps nr 91, s. 370 (edycja: KDmK II, nr 367; wydawca jednak błędne określił źródło, na którym oparł swoją edycję - otóż przysięgi służącego wójta i woźnego wprawdzie pochodzą z 1493 r., jednak wpisane są nie w księdze ławniczej, a w księdze wójtowskiej); ANK, rkps nr 82a, s. 2 (edycja: Księga wójtowska krakowska 1442-1443. Registrum domini advocati Cracoviensis 1442-1442. Ze zbiorów Archiwum Państwowego w Krakowie, wyd. M. Niwiński, K. Jelonek-Litewka, A. Litewka, Kraków 1995 [Fontes Cracovienses, 3], s. VIII).

${ }_{9}^{9}$ Kraków, Biblioteka Jagiellońska (dalej: BJ), rkps nr 16, k. 321r-327r.

${ }^{10} \mathrm{O}$ związkach tego gestu z przysięgą na słońce wywodzącą się jeszcze ze zwyczajów pogańskich, zob. W. Semkowicz, Jeszcze o przysiędze, s. 436-442. 
Po ślubowaniu monarcha uścisnął dłoń każdego z członków rady miejskiej. Nota o złożeniu przysięgi zawiera tekst przyrzeczenia w języku niemieckim. Jeszcze tego samego dnia rajcy krakowscy wystawili osobny dokument poświadczający te wydarzenia, w którym zamieścili tekst przysięgi złożonej w języku łacińskim ${ }^{11}$.

W księdze radzieckiej pod 1507 r., w niedzielę 25 stycznia, odnotowano złożenie przysięgi nowo obranemu królowi Zygmuntowi I, w podobnych okolicznościach jak w 1425 r.: ante pretorium in theatro cum baronibus regni in maiestate residente consulatus et communitas iuxta consuetudinem homagium prestitit et super pretorali archiepiscopi Gnesnensi iuramento solempniter confirmavit ${ }^{12}$.

Przy okazji przywołania relacji z 1425 r. warto wspomnieć również o incydencie ukazującym wagę przysięgi, którą mieszczanie zobowiązani byli złożyć królowi. Mianowicie podczas opisanej wyżej ceremonii z powodu choroby nieobecny był rajca Paweł Czech. Kilka dni po tym wydarzeniu, 8 marca, rajca ten został przywieziony do ratusza i wniesiony do izby wyższej - najpewniej wciąż walczył z chorobą - gdzie złożył królowi przysięgę wierności ${ }^{13}$.

Opisane wyżej wydarzenia dobitnie świadczą o tym, jak istotne było przyrzeczenie składane władcy przez poddanych; niewykluczone, że król wymagał tego zwłaszcza od ośrodków municypalnych (a szczególnie potężnego wówczas Krakowa), posiadających znacznie rozwiniętą samorządność i prowadzących własną politykę. Nadto Kraków (i jego zamożny patrycjat) w pewnym sensie odznaczał się w polityce kolejnych władców Królestwa zaciągających w mieście pożyczki ${ }^{14}$. Wobec tego nie dziwi fakt, że twórcy kopiariuszy uznali za zasadne, aby w zbiorach najważniejszych dla miasta tekstów uwzględnić homagia składane władcom przy okazji ich koronacji oraz roty przysiąg, które wypowiadali przedstawiciele najważniejszych instytucji funkcjonujących w Krakowie przed objęciem swoich stanowisk, ślubując rzetelne wykonywanie obowiązków oraz wierność - nie tylko społeczeństwu miejskiemu, ale także właśnie monarsze.

Wracając jednak do samych ślubowań, które rokrocznie składali mieszczanie sprawujący pewne funkcje, należy omówić zależność przysiąg pomieszczonych w dwóch wspomnianych wyżej kopiarzach, czyli w I kodyfikacji krakow-

${ }^{11}$ Najstarszy zbiór I, nr 18. Por. M. Rokosz, Forum Polonorum et Via Regia. Rynek krakowski i Droga Królewska scena wydarzeń państwowych, religijnych, narodowych i spolecznych 12572010, [w:] Rynek krakowski odkryty na nowo, red. E. Firlet, Kraków 2014, s. 502 (o hołdach składanych na rynku krakowskim zob. w pracy M. Rokosza, w podrozdziale pt. Hołdy pokoronacyjne na Rynku i hołd pruski, s. 497-514).

${ }^{12}$ ANK, rkps nr 431, s. 355-356. M. Rokosz przywołuje natomiast relację Jodoka Ludwika Decjusza dotyczącą tego wydarzenia, zob. M. Rokosz, op.cit., s. 503-504; J.L. Decjusz, Księga o czasach króla Zygmunta, thum. K. Kumaniecki et al., Warszawa 1960, s. 26-27.

${ }_{13}$ ANK, rkps nr 428, s. 216; M. Starzyński Krakowska rada miejska w średniowieczu, Kraków 2010 (Maiestas, Potestas, Communitas, 3), s. 198.

${ }^{14}$ Szerzej omówił to zagadnienie M. Starzyński (op. cit., s. 175-187). 
skiej i w Kodeksie Behema. Przede wszystkim uwagę zwraca wspomniana już wcześniej dysproporcja w liczbie rot, jakie zamieszczono w obu księgach; dla przypomnienia: w Kodeksie Grabowskiego jest ich dwadzieścia osiem, natomiast w Kodeksie Behema szesnaście (w tym jedna nowożytna). Niewątpliwie skryba notujący przysięgi w nowej księdze (jak współcześni zwali kopiarz tworzony w początku XVI w.) w ogromnej mierze korzystał ze starszego zbioru. Ten funkcjonował w krakowskiej kancelarii nieprzerwanie od drugiej połowy XIV w., a więc zawierał liczne skreślenia, uzupełnienia czy poprawki; z tego względu korzystanie z niego było utrudnione - wszakże część tekstów była nieaktualna, a estetyka i sama konstrukcja kodeksu zapewne utrudniała szybkie odnalezienie pożądanych fragmentów. Bardziej reprezentatywna wydaje się analiza zespołu rot zachowanych w Kodeksie Behema, ponieważ został on przygotowany według dobrze przemyślanego schematu, w którym niewątpliwie przejawiają się realia funkcjonowania miasta $-\mathrm{z}$ zachowaniem dalece posuniętej estetyki i, przede wszystkim, z dołączeniem indeksu ułatwiającego „nawigację” w całym, obszernym tomie. Dodatkowo należy zaznaczyć, że pomieszczone w nim teksty były aktualne na początku XVI w., a więc niewątpliwie pominięto roty, które na przestrzeni lat się zdezaktualizowały.

W nowym kopiarzu zawarto więc następujące teksty przysiąg:

1) k. 206v - przysięga prezydenta miasta, wpisana w języku polskim, najpewniej w XVIII w. (Iuramentum Dominorum Praesidentium Cracoviensium);

2) k. 207r-207v, 211r - przysięga rajców urzędujących, wpisana dwukrotnie: raz w języku polskim, raz w niemieckim (Iuramentum dominorum consulum presidencium);

3) k. 212r-przysięga pisarza miejskiego i jego zastępcy (Iuramentum notarii civitatis et vicenotarii);

4) k. 212v - przysięga ławników (Iuramentum scabinorum);

5) k. 213r - przysięga wójta (Iuramentum advocati);

6) k. $213 \mathrm{v}$ - przysięga podwójciego (Iuramentum viceadvocati);

7) k. 214r - przysięga starszych cechów (Iuramentum seniorum ex institutis, per quod cum ceteris czechmagistris annuatim confirmantur);

8) k. $214 \mathrm{v}$ - przysięga starszych (straży) na targu rybnym (Iuramentum seniorum de foro salsorum piscinum, quo annuatim electi, iurant et confirmantur);

9) k. 215r - przysięga wiertelników (Iuramentum quartaliensium);

10) k. 215 v - przysięga mistrzów rzemieślniczych, wpisana zarówno w języku niemieckim, jak i w thumaczeniu na język polski (Iuramentum mechanicorum, quo post dominorum consulum electionem annuatim confirmantur);

11) k. 216r - przysięga starszych kramarzy (Iuramentum tendlariorum, quo eorum seniores electi annuatim confirmantur);

12) k. 216v - przysięga kupców (Iuramentum civium mercatorum); 
13) k. 216v - przysięga rzemieślników miejskich i czeladników (Iuramentum civium mechanicorum et simplicium);

14) k. $217 \mathrm{r}$ - przysięga obywateli miasta podejrzanych o nieprawy handel (Iuramentum civium in mercanciis suspectorum, quod si prestare, qui suspectus est noluerit penam, quam domini consules statuerint reponat);

15) k. $217 \mathrm{r}$ - przysięga służących podejrzanych o nieprawy handel (Iuramentum famulorum in mercanciis suspectorum);

16) k. $217 \mathrm{v}$ - przysięga kupców, którzy, używając wolności rajcy, dopuścili się nadużyć (Iuramentum marcatorum, qui obtenta a dominis consulibus licencia ultra depositorium civitatis vadunt).

Wszystkie przysięgi wpisane są do księgi w języku niemieckim, tylko dwie z nich zostały dodatkowo przetłumaczone na język polski. Roty te znalazły się również w Kodeksie Grabowskiego, jednak w większości w nieco innych redakcjach. Warto w tym miejscu wymienić również te teksty, które w żadnej lekcji nie znalazły się w Kodeksie Behema, a które pojawiają się w I kodyfikacji. Są to ${ }^{15}$ :

1) przysięga urzędników nadzorujących wyszynk piwa (Iuramentum affusorum);

2) przysięga służących (Iuramentum famulorum);

3) przysięga piwowarów (Iuramentum braseatorum);

4) przysięga karczmarzy (Iuramentum tabernatorum);

5) przysięga pachołków miejskich (Iuramentum columbariorum);

6) przysięga wagowego przy wadze mniejszej (Iuramentum pensae minoris);

7) przysięga nadzorcy oraz pisarza wagi mniejszej (Iuramentum pensatoris et notarii predicte pense);

8) przysięga garbarza(?) (Iuramentum wergbinder);

9) przysięga zarządcy topni srebra (Iuramentum crematoris argenti);

10) przysięga mistrzów mincerskich (Iuramentum magistrorum monetae regiae);

11) przysięga nadzorcy wodociągów (Iuramentum aqueductoris, rormagistri);

12) przysięga obcych kupców, którzy zostali złapani na nieuczciwej sprzedaży (Iuramentum extraneorum, qui capta licencia ultra depositorium vadunt et in reditu, si domini habere voluerint, iurent eo modo, sive ex Hungaria, ex Lublin, Russia aut undecumque veniat);

13) przysięga wagowego (Iuramentum gewichteycher);

14) przysięga przyjmowanych do prawa miejskiego (Iuramentum suscepcionis iuris civilis).

\footnotetext{
15 ANK, rkps nr 1447a, s. 196-208 (edycja: Najstarszy zbiór, s. 44-52).
} 
Jak widać w przypadku obu kodeksów, są to przysięgi różnych grup zawodowych lub pomniejszych urzędników, zajmujących się na przykład kontrolą pracy konkretnych rzemieślników. W tym zestawieniu dziwić może to, że niektóre z tych rot nie znalazły się w Kodeksie Behema, jak choćby przysięga osób przyjmowanych do prawa miejskiego. Można to wyjaśnić - dość lakonicznie i niewyczerpująco - tym, że po prostu zamysł twórców Kodeksu Behema uwzględniał włączenie tylko tych piętnastu rot (nie wliczam późniejszej, zapewne XVIII-wiecznej przysięgi prezydenta miasta); możliwe jest, że kryterium doboru było podkreślenie istotnej roli krakowskiego samorządu oraz kupiectwa (o czym niżej).

Stanisław Estreicher, przygotowując edycję I kodyfikacji krakowskiej, nie wydał w całości wszystkich pomieszczonych tam przysiąg. Pominął te, które zostały już opublikowane przez Franciszka Piekosińskiego w drugiej części Kodeksu dyplomatycznego miasta Krakowa ${ }^{16}$. Uwzględnił jednak odmianki, jakie zachodzą pomiędzy tekstami ogłoszonymi wcześniej - należy dodać, że zostały one wydane właśnie na podstawie Kodeksu Behema (trzy dodatkowe wydano na podstawie ksiąg radzieckiej i wójtowskiej) - a tymi z Kodeksu Grabowskiego. W związku z powyższym analiza porównawcza I kodyfikacji i nowego kopiariusza jest ułatwiona, jakkolwiek Stanisław Estreicher w cytowaniu odmianek tekstowych nie był do końca precyzyjny. Wskazując różnice w tekstach przysiąg pomieszczonych w Kodeksie Grabowskiego i w Kodeksie Behema, wydawca pominął wiele różnic, a w przypadku niektórych przysiąg nie wynotował ich w ogóle. Z uwagi na fakt, że nie są one zasadnicze i nie wpływają na ogólne wnioski, nie ma potrzeby, aby w tym miejscu przywoływać je wszystkie. Dość wspomnieć, że różnice te dotyczą głównie szyku zdania (choć zmiany te są bardzo kosmetyczne), pomijania mniej istotnych słów (spójników, zaimków etc.) lub zamienianiu spójników na inne o tym samym lub podobnym znaczeniu. Ponadto należy odnotować, że pisarze Kodeksu Behema podczas kopiowania przysiąg modernizowali pisownię, czasami też nieco inaczej sformułowane są funkcje zawarte w nagłówkach poprzedzających tekst roty ${ }^{17}$.

Analiza pisma, jakim wpisano teksty do I kodyfikacji, wskazuje na to, że niektóre z nich zostały zanotowane równolegle ze spisywaniem Kodeksu Behema,

${ }^{16}$ KDmK II, s. 484-288. Wyjątkiem jest przysięga notariusza i wicenotariusza, którą Stanisław Estreicher podał w całości, mimo iż wersja tej roty w Kodeksie Grabowskiego zawiera tylko jedno dodatkowe słowo, które pominięto w Kodeksie Behema i które w żadnym stopniu nie zmienia sensu zdania. Mianowicie w pierwszej kodyfikacji zwrot brzmi und so beste das ich kan (ANK, rkps nr 1447a, s. 198), w późniejszym kopiarzu natomiast ten sam fragment zapisano: und zo bst ich kan (BJ, rkps nr 16, k. 212r).

${ }^{17}$ Na przykład w przypadku przysięgi notariusza i jego zastępcy w pierwszej kodyfikacji nagłówek brzmi Iuramentum notarii et subnotarii (ANK, rkps nr 1447a, s. 198), w Kodeksie Behema natomiast Iuramentum notarii civitatis et vicenotarii (BJ, rkps nr 16, k. 212r). 
bardzo podobnym (jeśli nie tym samym) pismem oraz, naturalnie, że roty zostały zamieszczone przez różne osoby, w różnym czasie (głównie w XV w.). Są to:

1) przysięga garbarza(?) (Iuramentum wergbinder);

2) przysięga zarządcy topni srebra (Iuramentum crematoris argenti);

3) przysięga podwójciego (Iuramentum viceadvocati);

4) przysięga nadzorcy wodociągów (Iuramentum aqueductoris, rormagistri);

5) przysięga mieszczan podejrzanych o nieprawy handel (Iuramentum concivium in mercantiis suspectorum);

6) przysięga służących podejrzanych o handel (Iuramentum famulorum concivium suspectorum);

7) przysięga obcych kupców, którzy zostali złapani na nieuczciwej sprzedaży (Iuramentum extraneorum, qui capta licencia ultra depositorium vadunt et in reditu, si domini habere voluerint, iurent eo modo, sive ex Hungaria, ex Lublin, Russia aut undecumque veniat);

8) przysięga wagowego (Iuramentum gewichteycher).

Wszystkie wymienione roty są wpisane na końcu pierwszej kodyfikacji. Trzy z nich pojawiają się także w Kodeksie Behema. Co ciekawe, wersje zamieszczone w obu kopiariuszach zawierają nieco więcej zmian w składni zdania niż inne skopiowane przysięgi. Również obecność innych rot potwierdza tezę, że ten fragment Kodeksu Behema nie bez powodu zawiera tylko te przysięgi - jego twórcy realizowali więc konkretny zamysł; w innym wypadku pomieściliby w kodeksie także i inne znane im roty.

W pierwszej kolejności warto omówić sam układ, w jakim rozmieszczono wymienione powyżej teksty w Kodeksie Behema. (W przypadku pierwszej kodyfikacji nie ulega większej wątpliwości, że kolejność ich wpisania była przypadkowa).

Średniowieczne przysięgi poprzedza miniatura Ukrzyżowanie ${ }^{18}$, którą umieszczono w tym miejscu dopiero $\mathrm{w}$ drugiej połowie XX w. Wcześniej znajdowała się w tylnej oprawie rękopisu, później, najpewniej podczas wykonywania nowej oprawy w 1878 r., deska okładki tylnej z Ukrzyżowaniem stała się deską okładki górnej. W miejscu, w którym znajduje się obecnie, umieścił ją Stanisław Cendorowicz w 1986 r., kiedy wykonywał nową (czwartą z kolei) oprawę kodeksu' ${ }^{19}$.

W większości przypadków przysięgi wpisywane były na osobnych stronach; wyjątek stanowią: przysięga kupców, przysięga rzemieślników miejskich i cze-

\footnotetext{
${ }^{18}$ BJ, rkps nr 16, k. 207a.

19 B. Bucher, Die Alten Zunft- und Verkehrs-Ordnungen der Statdt Krakau. Nach Balthasar Behem's Codex Picturatus in der k.k. Jagellonischen Bibliothek, Wien 1889, s. IX; A. Sobańska, Kodeks Baltazara Behema. Komentarz kodykologiczny, Kraków 2007, s. 16.
} 
ladników ${ }^{20}$ oraz przysięgi obywateli miejskich podejrzanych o nieprawy handel, a także służących (famuli) podejrzanych o ten sam występek ${ }^{21}$. Wszystkie roty zostały wpisane bardzo starannie, brak przy nich jakichkolwiek poprawek, uzupełnień i glos lub odsyłaczy na marginesach.

Starannością wyróżniają się teksty przysięgi rajców. Jako pierwsza została wpisana przysięga w języku polskim ${ }^{22}$. Następnie, po pozostawieniu trzech pustych kart, wpisano tę samą przysięgę w języku niemieckim ${ }^{23}$. Tę również skreślono większym modułem pisma niż inne przysięgi, jednak mniejszym niż przysięgę rajców w języku polskim.

Należy zwrócić uwagę na to, że choć przysięga w języku polskim została wpisana na wcześniejszych kartach, to bez wątpienia zamieszczono ją tam nieco później. Ręka, jaką wpisano tę rotę, jest podobna do tej, która wpisała iuramentum rajców w języku niemieckim, nie jest jednak identyczna. Dostrzegalne są zasadnicze różnice w sposobie kreślenia niektórych liter oraz brak zdobnego inicjału, który w różnej formie pojawia się w przypadku innych rot. Uwagę zwraca również nieco inny odcień czerwieni w nagłówku poprzedzającym tekst przysięgi. Jest on zdecydowanie ciemniejszy aniżeli inne fragmenty i elementy tekstu wpisane do Kodeksu Behema czerwonym atramentem. Nadto nie została ona pierwotnie uwzględniona $\mathrm{w}$ tematycznym spisie treści na końcu księgi, a adnotacja o przysiędze rajców w języku polskim wpisana jest tam znacznie później - na marginesie i czarnym atramentem ${ }^{24}$.

Warte odnotowania jest również to, że poza przysięgą rajców jeszcze tylko przysięga rzemieślników została wpisana i w języku niemieckim i w języku polskim $^{25}$. Tym razem obie wersje wpisano na jednej stronie - po tekście w języku niemieckim słowami Eorundem et idem in Polonico wpisanymi in rubro poprzedzono thumaczenie roty na język polski.

Taki układ przysiąg został przez twórców kodeksu głęboko przemyślany. Kolejność, w jakiej ułożono roty, dość jednoznacznie wskazuje na hierarchię instytucji miejskich Krakowa. Przełom XV i XVI w. to czas, kiedy rada miejska bezdyskusyjne stanowiła najważniejszy organ samorządowy, decydowała zarówno o sprawach wewnętrznych, jak i zewnętrznych miasta, a także reprezentowała całą krakowską społeczność na forum państwowym ${ }^{26}$. Nie ulega więc wątpliwo-

${ }^{20}$ BJ, rkps nr 16, k. 216v.

${ }^{21}$ Ibidem, k. 217 r.

${ }^{22}$ Ibidem, k. 207r-207v.

${ }^{23}$ Ibidem, k. 211 r.

${ }^{24}$ Ibidem, k. 353r.

${ }^{25}$ Ibidem, k. $215 \mathrm{v}$

${ }^{26}$ M. Patkaniowski, Krakowska rada miejska w średnich wiekach, Kraków 1934 (Biblioteka Krakowska [dalej: BK], 82), s. 46-47; J. Wyrozumski, Kraków do schyłku wieków średnich, Kra- 
ści, dlaczego właśnie rota przysięgi rajców została umieszczona na czele tej części kodeksu oraz wyróżniona formą.

Na drugim miejscu wymieniono przysięgę pisarza miejskiego i jego zastęp$\mathrm{cy}^{27}$. Notariusz nie był pisarzem sensu stricto, ale stał na czele kancelarii miejskiej, która - poza tym, że prowadziła dokumentację z działalności instytucji miejskich - stanowiła niejako narzędzie, za pomocą którego władze samorządu zarządzały miastem. Pisarz miejski należał ponadto do zarządu miasta, nie będąc rajcą brał udział w posiedzeniach rady miejskiej, towarzyszył jej członkom w podróżach politycznych, a czasem sam podejmował wyprawy, by załatwiać różne miejskie sprawy. Zapewne w chwili, kiedy notariusz nie był w stanie samodzielnie wykonywać wszystkich swoich zadań - zresztą bardzo licznych ${ }^{28}$ - na przykład podczas gdy udał się w delegację, robił to jego zastępca, prawdopodobnie o podobnych, jeśli nie takich samych, kompetencjach. Należy również przypomnieć, że stanowisko to obejmowały osoby dobrze wykształcone ${ }^{29}$.

Wprawdzie według hierarchii urzędniczej przyjętej w mieście średniowiecznym przysięga notariusza powinna była znaleźć się tuż po rotach ławników i wójta (oraz podwójciego), ponieważ ten pierwszy nie należał do grona władz miejskich, a był ,jedynie” pracownikiem zatrudnianym przez te władze, jakkolwiek jego pozycja w mieście była nadzwyczaj wysoka - miał on niebagatelny wpływ na prowadzenie polityki ośrodka, zarówno wewnętrznej, jak i zewnętrznej. Wiadomo wszakże, że notariusz potrzebny był nie tylko w trudnych czy konfliktowych sytuacjach mających miejsce wewnątrz gminy ${ }^{30}$, ale również podczas rozwiązywania sporów zewnętrznych lub, jak wspomniano, w ogóle podczas wyjazdów dyplomatycznych. Notariusz krakowski brał udział w takich podróżach nie tylko jako pomocnik czy towarzysz rajców - jak na przykład podczas zjazdu w Raciążu w 1414 r., kiedy zawarto rozejm polsko-litewsko-krzyżacki ${ }^{31}$,

ków 1992 (Dzieje Krakowa, 1, red. J. Bieniarzówna, J.M. Małecki), s. 421; M. Starzyński, op. cit., passim, zwł. 133-205.

${ }^{27}$ Warto wspomnieć, że w Niemczech przysięga notariusza (jak również inne przysięgi) przybierały nieco inne brzmienie, były obszerniejsze i bardziej „szczegółowe”, zob. m.in. P. Hoheisel, Die Göttinger Stadtschreiber bis zur Reformation. Einfluß, Sozialprofil, Amtsaufgaben, Göttingen 1998 (Studien zur Geschichte der Stadt Göttingen, 21), s. 12-14.

${ }^{28}$ Zob. G. Roth Zwischen Pflicht und Kür. Der Stadtschreiber Peter Eschenloer als Botschafter, Übersetzer und Chronist. Mit drei Anhängen zu Gestanden, Prokuratoren und Boten des Breslauer Rates, [w:] Stadt, Kanzlei und Kultur im Übergang zur Frühen Neuzeit. City Culture and Urban Chanceries in an Era of Change, hrsg. von R. Suntrup, J.R. Veenstra, Frankfurt am Main 2004, s. 15-46.

${ }^{29}$ A. Bartoszewicz, Piśmienność mieszczańska w późnośredniowiecznej Polsce, Warszawa 2013, s. 133-134, 144-152.

${ }^{30}$ A. Gąsiorowski, Walki o władzę w Poznaniu u schyłku wieków średnich, „Kwartalnik Historyczny" 82 (1975), z. 2, s. 256-261.

${ }^{31}$ Rozejm ten, według Zenona Nowaka (Z. Nowak, Polityka pótnocna Zygmunta Luksemburskiego do roku 1411, Toruń 1964 [Roczniki Towarzystwa Naukowego w Toruniu, 69/1], s. 60-61), 
czy ogólnie jako jeden z reprezentantów miasta na sejmach Królestwa Polskiego, zjazdach miast lub podczas wyjazdów zagranicznych ${ }^{32}$ - ale również wyjeżdżał sam. Księgi rachunkowe informują o jego samodzielnych wyjazdach nie tylko z wizytą do króla ${ }^{33}$ czy starosty ${ }^{34}$, ale także w podróże poza granice Korony - na Litwę czy Węgry. Tak istotną rolę notariusz miejski pełnił nie tylko w Krakowie, ale także w innych ośrodkach objętych niemiecką kulturą prawno-ustrojową; o tym świadczy choćby uchwała zjazdu miast hanzeatyckich z 1418 r. stanowiąca, że posłami na zgromadzenia Hanzy mogą być wyłącznie członkowie rady miejskiej, a pisarz miasta może być tam obecny wyłącznie w charakterze towarzysza czy pomocnika, nie zaś jako samodzielny reprezentant gminy (w późniejszym okresie postanowienie to było ponawiane) $)^{35}$. Widać więc, jak wysoką pozycją cieszył się notarius civitatis - w praktyce jego kompetencje i możliwości były zdecydowanie większe aniżeli członków ławy czy wójta.

Dopiero kolejno wpisano przysięgi ławników, wójta i podwójciego. Przede wszystkim dokładnie obrazuje to przetasowania, do których doszło od lokacji miasta Krakowa w 1257 r. po koniec XV w. Momentem przełomowym w dziejach krakowskiego wójtostwa - pierwotnie stanowiącego główną instytucję samorządową Krakowa - była rebelia mieszczan z lat 1311-1312, na czele której stanął wójt Albert. Ten sprzeciw wobec Władysława Łokietka sprowadził na miasto przykre konsekwencje, które najmocniej dotknęły właśnie urząd wójtowski. Po tych wydarzeniach rada miejska stopniowo zaczęła zwiększać swoje prerogatywy tak, że w XV w. wójt był już najniższym urzędnikiem w hierarchii instytucji samorządowych, posiadał właściwie tylko kompetencje sądowe i był niemal całkowicie podporządkowany rajcom. Ostatecznie w 1475 r. rada miejska wykupiła wójtostwo od Piotra Langa, a rajcy podjęli uchwałę, że wójt ma być wybierany z pospólstwa, nie z grona rajców ${ }^{36}$. Kolejność, w której przysięgi wójta i podwój-

należy łączyć z mającym miejsce w 1404 r. zjazdem w Sączu, podczas którego spotkać się mieli Władysław Jagiełło i Zygmunt Luksemburski, a w którym uczestniczyli również przedstawiciele miasta Krakowa (Najstarsze księgi i rachunki miasta Krakowa od r. 1300 do 1400, wyd. F. Piekosiński, J. Szujski, cz. II, Kraków 1878 [MMAE, 4], s. 276). Nadto warto wspomnieć, że notariusz Piotr bardzo często towarzyszył rajcom w podróżach dyplomatycznych. Z pewnością był bliskim współpracownikiem władz miejskich - zresztą podobnie było najpewniej także w przypadku innych pisarzy miejskich. Biogram Piotra zob. B. Wyrozumska, Kancelaria, s. 119-120.

${ }^{32}$ Najstarsze księgi, s. 237, 243, 249, 257, 259, 262, 273, 276, 286, 288.

${ }^{33}$ Ibidem, s. 232, 237, 243, 270, 276, 279, 283, 286.

${ }^{34}$ Ibidem, s. 237, 244.

35 J. Tandecki, Dokumenty i kancelarie miejskie, [w:] Dyplomatyka staropolska, red. T. Jurek, Warszawa 2015, s. 416. W 1486 r. odmówiono także pertraktacji z pisarzem miejskim Getyngi (P. Hoheisel, Die Göttinger Stadtschreiber, s. 180).

${ }^{36}$ KDmK II, nr 337; M. Niwiński, Wójtostwo krakowskie w wiekach średnich, Kraków 1938 (BK, 95), s. 44-59, 89. Warto zauważyć, iż nie był to wykup sensu stricto, a jedynie zastaw w ra- 
ciego znalazły się po przysięgach rady i ławy (a także notariusza i wicenotariusza), jest więc wiernym odzwierciedleniem stosunków poszczególnych organów miejskich w ustroju municypalnym Krakowa.

Wyjaśnienia wymaga również kwestia tego, że dla wójta i podwójciego wpisano osobne przysięgi, a nie jak w przypadku notariusza i wicenotariusza - jedną. W tym miejscu należy przypomnieć, że o ile wicenotariusz był de facto zastępcą głównego pisarza - pod jego nieobecność przejmował jego obowiązki, a zapewne także na co dzień wyręczał go w niektórych zadaniach - to w przypadku podwójciego sytuacja była zgoła odmienna. Mieczysław Niwiński dowiódł, że zastępcy wójta i podwójciego nie należy ze sobą utożsamiać. Zastępca wójta, zwany w wówczas unterrichter czy undirrichter, a w źródłach sądowych z XV w. często po prostu advocatus, powoływany był doraźnie przez wójta spośród rajców lub ławników, kiedy wójt nie mógł wykonywać swoich obowiązków. Podwójci natomiast był najważniejszym z pomocników wójta, należał do jego familiares; pełnił funkcje przede wszystkim pisarza wójta, o czym świadczy chociażby właśnie przysięga umieszczona w Kodeksie Behema. Wprawdzie rota ta zawiera informację również o sądzeniu, czy też pomocy w sądzeniu, jednak, jak skonkludował wspomniany badacz: ,ponieważ nigdy nie spotykamy podwójciego w charakterze przewodniczącego sądu ławniczego, więc przyjąć należy, że podwójci zastępował wójta w sądzie potocznym, jednostkowym wójtowskim, natomiast na posiedzeniach sądu ławniczego pomagał tylko właściwemu zastępcy wójta"37.

W dalszej kolejności w Kodeksie pojawiają się przysięgi przedstawicieli cechów; układ tychże zapewne również odpowiada „hierarchii ważności”, która nieformalnie obowiązywała $\mathrm{w}$ mieście. Na koniec zaś przywołano roty wypowiadane przez mieszczan, którzy z kolei, dokonując transakcji handlowych, w różny sposób dopuścili się nadużyć. Istotne jest, aby zwrócić uwagę, iż dla każdej grupy mieszczan wpisano osobną przysięgę. Ponadto fakt, że przysięgi te dotyczą wyłącznie sfery handlowej, pomijając inne występki, jakich krakowianie z pewnością się dopuszczali, i jakie można znaleźć w przysięgach pomieszczonych w innych źródłach, dość jasno wskazuje na dziedzinę życia (gospodarki), jaka dla Krakowa była najważniejsza ${ }^{38}$. Poparciu tej tezy może służyć fakt, że poza przysięgami urzędników miejskich w omawianym kodeksie odnotowano wyłącznie przysięgi grup zawodowych związanych z handlem - wyjątkiem jest tu przysięga mistrzów rzemieślniczych i czeladników, ale została ona wpisana nie-

mach zabezpieczenia sumy dłużnej przez skarb królewski; suma ta jednak nigdy nie została spłacona, stąd rada niezmiennie była w posiadania wójtostwa (zob. ibidem, s. 89).

${ }_{37}$ M. Niwiński, op. cit., s. 123-129.

${ }^{38} \mathrm{Na}$ zasadniczą rolę handlu zwracał już uwagę Henryk Samsonowicz w swojej klasycznej pracy dotyczącej dziejów miast w średniowiecznej Polsce (M. Bogucka, H. Samsonowicz, Dzieje miast i mieszczaństwa w Polsce przedrozbiorowej, Wrocław 1986, s. 178-200). 
jako razem z przysięgą kupców, na tej samej stronie i zawiera niemal identyczną treść (z pominięciem końcowego fragmentu roty); zresztą jest ona jedna, wspólna dla wszystkich rzemiosł. Wszakże według not zawartych w księgach radzieckich starsi cechowi składali przysięgi zazwyczaj tego samego dnia (choć nie było to regułą, o czym świadczy to, że pomiędzy nazwiskami starszych różnych cechów często pojawiają się inne wpisy) ${ }^{39}$, a skoro sformułowana była jedna przysięga dla mistrzów rzemieślniczych, zapewne właśnie ją wypowiadali.

W tym kontekście zastanawiające jest, dlaczego istniała osobna przysięga dla mistrzów cechu kupców. Według not w księgach radzieckich zdarzało się, że elekcji starszych wszystkich rzemiosł dokonywano innego dnia aniżeli właśnie starszych cechu kupców. Na przykład w 1410 r. wyboru starszych dla wszystkich rzemiosł dokonano w sobotę 31 maja $^{40}$, zaś starszych kupców dopiero w piątek 1 sierpnia $^{41}$. Na podstawie powyższych przesłanek można wyciągnąć wniosek o innym charakterze zgromadzenia kupców aniżeli w przypadku wszystkich pozostałych rzemiosł. Wszak osobne przysięgi w Kodeksie Behema posiadają niemal wyłącznie urzędnicy miejscy lub przedstawiciele władzy, jak na przykład wiertelnicy. Zresztą elekcji seniorum quartalium także dokonywano innego dnia i notowano osobno, nie razem z elekcją starszych cechów ${ }^{42}$ - tak, jak wyglądało to w kontekście elekcji na przykład ławników, których rajcy wybierali, od około połowy XIV w., zazwyczaj latem, w lipcu lub sierpniu, w przypadkowe dni tygodnia, ale nigdy w niedzielę ${ }^{43}$, wcześniej daty te są bardzo różne ${ }^{44}$; podobnie zresztą, jak w przywołanym wyżej przykładzie z 1410 r., kiedy osobno wpisano elekcję starszych kupieckich.

Wiadomo, że warstwa kupiecka stanowiła bez wątpienia elitę majątkową Krakowa, to z niej rekrutowali się rajcy miejscy; była to też najbardziej ekskluzywna grupa w mieście. Według Hanny Zaremskiej członkowie (lub przyszli członko-

${ }^{39}$ ANK, rkps nr 427, s. 203-205, 307-309, 357-358; ibidem, rkps nr 428, s. 126, 139-141, 158 161, 183-186; ibidem, rkps nr 430, s. 453-454, 515-516, 547-548; ibidem, rkps nr 431, s. 37-41.

${ }^{40}$ Ibidem, s. 373-374.

${ }^{41}$ Ibidem, s. 377.

${ }^{42}$ Ibidem, rkps nr 427, s. 68; ibidem, rkps nr 428, s. 66, 164, 178, 186, 228, 272, 433; ibidem, rkps nr 429, s. 56, 292, 353, 415.

${ }^{43}$ Księgi ławnicze krakowskie 1365-1376 i 1390-1397, wyd. S. Krzyżanowski, Kraków 1904 (Wydawnictwa Archiwum Aktów Dawnych Miasta Krakowa, 1), s. 48, 129, 162, 190, 222, 253, 284, 302; ANK, rkps nr 4, s. 30, 51, 68, 86, 114; ibidem, rkps nr 5, s. 7, 28, 46, 62, 74, 95, 107, 145, 169, 186, 208; ibidem, rkps nr 6, s. 14, 63, 88, 111, 130, 148, 163, 180, 208, 237, 268, 284, 336; ibidem, rkps nr 7, s. 13, 41, 62, 97, 121, 149, 177, 202, 229, 267, 289, 340; ibidem, rkps nr 8, s. 48, 88, 119, 151, 183, 218, 262, 338, 371, 406, 441, 473, 509, 543, 578.

${ }_{44}$ Najstarsze księgi i rachunki miasta Krakowa od r. 1300 do 1400, wyd. F. Piekosiński, J. Szujski, cz. I, Kraków 1878 (Wydawnictwa Komisyi Historycznej Akademii Umiejętności w Krakowie, 5), s. 4-9, 12-13, 16, 25, 32-34, 36, 41, 53, 55, 62, 66, 69, 76-77, 87, 98, 103, 167, 170, 173, 176, 181, 186, 191, 193. 
wie) rady miejskiej zrzeszali się w elitarnym bractwie modlitewnym działającym przy kościele Mariackim, czyniąc tę konfraternię zbiorowiskiem ludzi złączonych ze sobą zawodowo czy politycznie ${ }^{45}$. Wprawdzie Jerzy Rajman w ostatnich latach zweryfikował tezy tej badaczki, zwracając uwagę, że w księdze zmarłych bractwa wpisano również imiona osób niezwiązanych z elitą władzy, jak „,zwykłych” rzemieślników czy nawet żebraków, jednak jednocześnie przyznał, że konfraternia zdominowana była właśnie przez kupców ${ }^{46}$. Sensu largo należy więc zgodzić się, ze wspomnianą Hanną Zaremską, która konkludowała, że „słabość, a zwłaszcza luźny charakter znanych nam polskich kongregacji kupieckich należałoby thumaczyć (...) ich bezużytecznością, powodowaną dublowaniem funkcji rady.”47. Być może właśnie z tego względu - przejęcia „kompetencji” cechu kupców przez kupców zrzeszonych w radzie miejskiej i wspomnianym bractwie - wynikają przedstawione wyżej nieścisłości związane z wyborami starszych tego cechu.

Warto zwrócić uwagę także na samą treść przysiąg. Teksty te są bardzo sztampowe, wszystkie zawierają bowiem odniesienia do charakteru poszczególnych stanowisk czy - w przypadku rzemieślników - zawodów. Rajcy byli jedyną grupą (spośród składających wyżej wymienione przysięgi), która przysięgała wierność jedynie Bogu i monarsze oraz, naturalnie, państwu oraz miastu; inne grupy dodatkowo ślubowały bezwzględne podporządkowanie się rajcom. Jest to dość oczywiste z punktu widzenia obowiązków i odpowiedzialności ciążących na członkach rady miejskiej, którzy - ujmując to w dużym skrócie - mieli za zadanie dbać o dobro i jedność municypium. Roty informują nas pośrednio także o obowiązkach poszczególnych urzędników czy zawodów: notariusz zobowiązany był sumiennie zapisywać wszelkie czynności prawne, zachowywać $\mathrm{w}$ tajemnicy prowadzone sprawy oraz pogłębiać swoją wiedzę; ławnicy ślubowali sprawiedliwe sądzenie oraz znajomość prawa; wójt obiecywał wspierać ławników w ferowaniu wyroków, zastępca wójta (viceadvocatus) wpisywać skrupulatnie do ksiąg wszelkie sprawy prowadzone przez wójta, wydawać świadectwa spraw oraz zarządzać

${ }^{45}$ H. Zaremska, Bractwa w średniowiecznym Krakowie. Studium form społecznych życia religijnego, Wrocław 1977, s. 68-70 i n.

${ }_{46}$ J. Rajman, Unsere liebe Fraue. Wspólnota miasta i kościoła w Krakowie w XIV wieku, „Średniowiecze Polskie i Powszechne" (dalej:ŚPiP) 4 (8) [2012], s. 150-201, zwł. 187-189 (tam dane liczbowe dotyczące członków bractwa); idem, Żebrak, sługa i rzemieślnik w elitarnym bractwie Najświętszej Marii Panny w Krakowie (XIV-pierwsza połowa XVI wieku), ŚPiP, 6 (10) [2014], s. 140-157.

${ }^{47}$ H. Zaremska, Miasto: struktury społeczne i styl życia, [w:] Kultura Polski średniowiecznej, red. B. Geremek, Warszawa 1997, s. 198. Zob. też: E. Cieślak, Walki ustrojowe w Gdańsku i Toruniu oraz w niektórych miastach hanzeatyckich w XV w., Gdańsk 1960, s. 93-96; J. Wyrozumski, Korporacje zawodowe i religijne w średniowiecznym Krakowie, [w:] idem, Cracovia mediaevalis, Kraków 2010, s. 215 [pierwodruk w: Documenta pragensia. Od středověkých bratrstev k moderním spolkům, Praha 2000, s. 19-26]. 
opłatami, które miały trafić do jego zwierzchnika; kupcy i rzemieślnicy zobowiązywali się rzetelnie wykonywać swoją pracę, tworzyć produkty zawsze tak samo dobrej jakości i sprzedawać je na uczciwych warunkach, bez względu na to, kto byłby ich kupcem; wiertelnicy natomiast ślubowali strzec prawa i porządku w mieście, za dnia i w nocy. Ciekawe jest, że teksty przysiąg rzemieślników miejskich i sprzedawców zawierały również fragmenty, w których zobowiązywali się oni do informowania rajców o kradzieżach i cudzołóstwie wewnątrz cechów.

Formuły przysiąg odnotowane w Kodeksie Grabowskiego pozwalają śledzić, jak ich treść zmieniała się mniej więcej od końca XIV w. Przy przekreślonej, zmienianej i uzupełnianej wcześniej kilkukrotnie przysiędze rzemieślników (Iuramentum mechanicorum) odnotowano nawet, kiedy i w jakiś okolicznościach rota została zmieniona ${ }^{48}$, po czym wpisano nową formułę, nazwaną już Iuramentum magistrorum mechanicorum, ale niedługo później wpisano ponownie tę przysięgę, nieznacznie zmienioną. Co ciekawe, nie jest to przysięga, która znalazła się w Kodeksie Behema pod tytułem Iuramentum mechanicorum, quo post dominorum consulum electionem annuatim confirmantur; w nowej księdze w ogóle nie występuje rota o tej treści, lecz trudno stwierdzić, czy można zakładać, że iuramenta te składane były przez tę samą grupę.

Reszta przysiąg zawartych w Kodeksie Grabowskiego nie różni się lub różni się w bardzo niewielkim stopniu od tekstów zwartych w Kodeksie Behema, stąd nie ma uzasadnienia, by szczegółowo je omawiać. Wciąż jednak zastanawia, dlaczego w pierwszej kodyfikacji rot tych jest znacznie więcej. Przysięgi, których zabrakło w nowym kopiarzu, to częściowo przysięgi poszczególnych przedstawicieli rzemiosł, których treść zasadniczo niewiele się od siebie różniła - wszyscy ślubowali sumienne wykonywanie swojej pracy i uczciwe warunki jej sprzedaży. Być może, jak już wcześniej wspomniano, na początku XVI w. przedstawiciele wszystkich cechów składali to samo przyrzeczenie i właśnie dlatego w nowo tworzonym kopiarzu zawarto tylko jedną rotę dla rzemieślników. To w pewien sposób thumaczyłoby również fakt, że przysięga tych samych (?) grup ma inną treść. Jeśli chodzi o iuramenta, jakie składali pracownicy będący na usługach miasta, jak np. pachołkowie miejscy czy zarządca topni srebra, wydaje się, że po prostu w tak dostojnej księdze odnotowano tylko te grupy krakowskiej społeczności, które były wizytówką miasta, zwłaszcza że, co zostało już zaznaczone, do pierwszej kodyfikacji niektóre z tych tekstów wpisano współcześnie do tworzenia Kodeksu Behema. Niewątpliwie Najstarszy zbiór wciąż był używany w krakowskiej kan-

48 Istud iuramentum mutatum est cum consensu omnium seniorum mechanicorum feria quarta die Cinerum anno etc. mccccVII (9 lutego 1407) in iuramentum in presenti columpna subscriptum, quod omnes magistri mechanicorum iuraverunt et iurandum de cetero assumpserunt perpetuis temporibus affuturis (Najstarszy zbiór, s. 44; ANK, rkps nr 1447a, s. 196). 
celarii, o czym, poza obecnością w nim ręki pisarskiej znanej z nowego kopiarza, świadczą także dopiski nowożytne, również - co istotne - glosy w języku polskim wpisane pomiędzy wersy niemieckojęzycznych przysiąg (a także obok lub pod nimi), tłumaczące treść tych rot.

Właściwie w bardzo podobnym brzmieniu przysięgi urzędników miejskich (nie wszystkich) znalazły się w dziele Bartłomieja Groickiego powstałym w XVI w., naturalnie spisane w języku polskim ${ }^{49}$. Ten teoretyk prawa i pisarz Sądu Najwyższego Prawa Niemieckiego na zamku krakowskim podjął się przetłumaczenia podstaw prawa magdeburskiego, czyli Speculum Saxonum oraz Ius Municipale Magdeburgense. Tłumaczenia te są jednak mało skrupulatne, prawdopodobnie dlatego, że zamiarem Groickiego było jedynie ułatwić prace odpowiednim organom władzy, ponieważ zauważył, iż członkowie tych instytucji bardzo często nie władają biegle łaciną ${ }^{50}$. Niemniej powyższa analiza wskazuje, że roty te nie zmieniały zanadto swojej treści co najmniej od końca XIV w., ulegały tylko niewielkim przekształceniom językowym.

Nieco miejsca należy również poświęcić samej formie składania tychże przyrzeczeń. W związku z tym, że nie zachowały się źródła, które informowałyby, w jaki sposób przebiegały wybory na stanowiska inne niż rajców, pozostaje skupić się na wyborach tych ostatnich. Wiele informacji na ten temat przywołał już Zdzisław Noga odnośnie do wyborów krakowskiej rady miejskiej w XVI w.

Wiadomo, że w Krakowie wybory rajców odbywały się zazwyczaj na początku roku, tradycyjnie miała to być niedziela po święcie Trzech Króli (6 stycznia), jakkolwiek w Krakowie termin ten nie był konsekwentnie przestrzegany - ani w średniowieczu, ani w czasach późniejszych nie wyklarował się konkretny termin, w którym rokrocznie dokonywano wyboru nowej rady, na co miały wpływ czynniki zewnętrzne takie jak nieobecność wojewody, klęski elementarne, inne uroczystości (dworskie lub państwowe) ${ }^{51}$. Sporo miast europejskich również dokonywało wyborów rady na początku roku kalendarzowego, jakkolwiek było od tej zasady wiele wyjątków, a elementem wspólnym było jedynie dokonywanie elekcji w dzień, na który przypadało święto nieruchome ${ }^{52}$.

49 B. Groicki, Porzadek sadów i spraw miejskich prawa majdeburskiego w Koronie Polskiej, wyd. K. Koranyi, Warszawa 1953, s. 31 (przysięga radziecka), 33 (przysięga wójtowska), 37 (przysięga ławników), 40 (przysięga pisarza), 52-55 (przysięgi starszych z cechów, przyjmujących prawo miejskie, sług miejskich, podwójciego, sługi podwójciego).

${ }^{50}$ K. Koranyi, Wstęp, [w:] ibidem, s. V-XII.

${ }_{51}$ Z. Noga, Krakowska rada miejska w XVI wieku. Studium o elicie władzy, Kraków 2003, s. 23; M. Starzyński, op. cit., s. 84-85.

52 D.W. Poeck, Rituale des Ratswahl. Zeichen und Zeremoniell der Ratssetzung in Europa 12.18. Jahrhundert, Köln-Weimar-Wien 2003 (Städteforschung. Reihe A, Darstellungen, 60), s. 3, 67-154, zwł. 154. 
W każdym razie w Krakowie podczas wyborów wojewoda dokonywał uroczystej nominacji rajców, którzy mieli sprawować ten urząd przez rok. Ceremoniał towarzyszący legitymizacji władzy i podkreśleniu roli politycznej miasta i samej rady był bardzo uroczysty i kosztowny. Odnośnie do Krakowa nie mamy szczegółowych relacji dotyczących tego wydarzenia, jakkolwiek można założyć, że wyglądało to podobnie jak w miastach zachodnioeuropejskich. Do uczestniczenia w uroczystości zwoływał krakowian trębacz z wieży kościoła Mariackiego; miało to miejsce w chwili, gdy wojewoda schodził z Wawelu na mszę do tego kościoła. Po mszy uczestnicy udawali się do ratusza, gdzie zapewne odczytywano dokument wojewody zawierający nazwiska nowo obranych rajców. Można zakładać, że potem następowało złożenie ślubowania. Ceremoniał składania przysięgi miał podkreślać autonomię rady miejskiej; Roman Czaja zauważył, że w miastach nadbałtyckich nowo obrani rajcy składali przysięgę wobec rady, a zwykłych mieszczan informowano tylko o wynikach wyborów ${ }^{53}$. Niewątpliwie był to wyraz ekskluzywizmu i niezależności charakterystycznych dla miejskiej elity władzy. Następnie znów udawano się do kościoła Mariackiego, w którym nowa rada miejska zajmowała miejsce w stallach radzieckich, aby wziąć udział w mszy dziękczynnej zamykającej uroczystość. Kolejnym punktem było przyjęcie w ratuszu, na które często przybywał nawet sam monarcha ${ }^{54}$. Doświadczenie miast niemieckich pozwala zakładać, że nominacja nowego składu rady miejskiej, a zwłaszcza towarzyszące jej wystawne przyjęcie, była wydarzeniem przepełnionym przepychem, manifestacją zamożności rajców i potęgi miasta ${ }^{55}$.

Co się zaś tyczy nominacji na stanowiska starszych cechów oraz na inne funkcje w szeroko rozumianym zarządzie miasta - na ten temat mamy niewiele informacji. Można przypuszczać, że sam ceremoniał naśladował w pewien sposób wybór rajców, lecz z pewnością, co oczywiste, nie był tak wystawny i pełen przepychu. Wiadomo, że elekcji na wspomniane stanowiska dokonywali rajcy, a daty pomieszczone w księgach radzieckich dowodzą, że zazwyczaj działo się to na początku roku, po wyborach nowego składu rady miejskiej, choć niekoniecznie tego samego dnia. Zważywszy na fakt, że rzadko podane są konkretne daty dzienne wyborów, a także pomiędzy wykazami nowo wybranych w danym roku czasami znajdują się inne zapiski ${ }^{56}$, można przypuszczać, że starsi poszczególnych cechów nie zawsze byli wybierani tego samego dnia. Oczywiste jest, że co roku nazwiska wybranych starszych cechów, jak i urzędników miejskich,

${ }^{53}$ R. Czaja, Grupy rządzące w miastach nadbattyckich w średniowieczu, Toruń 2008 (Roczniki Towarzystwa Naukowego w Toruniu, 93, z. 1), s. 91.

${ }^{54}$ Z. Noga, op. cit., s. 23-30.

55 Jak wystawnie mogło być świętowanie tego dnia świadczy przykład miasta Soest w zachodnich Niemczech, gdzie feta trwała trzy dni, zob. D.W. Poeck, op. cit., s. 87-100 (w tejże publikacji autor bardzo szczegółowo omówił ceremoniał wyboru rajców w wybranych miastach europejskich, niestety z wyłączeniem miast Królestwa Polskiego, zob. ibidem, passim).

${ }^{56} \mathrm{O}$ tym zob. we wcześniejszej partii niniejszego tekstu. 
zazwyczaj się powtarzały, gdyż „władzę”, zarówno w mieście, jak i w poszczególnych instytucjach funkcjonujących w społeczeństwie miejskim, często przez wiele lat, trzymały bez przerw te same osoby, zatem ślubowanie to było dla nich jedynie odnowieniem składanej już przysięgi. Można zakładać, że należało to do obowiązków, ponieważ w księgach miejskich dość skrupulatnie odnotowywano nazwiska nowo obranych urzędników.

Zapewne też, jak zaznaczono, nie wszyscy składający wyżej wspomniane przyrzeczenia robili to jednego dnia czy nawet na początku roku. Wiadomo, że losy wójtostwa krakowskiego zmieniały się w ciągu całego średniowiecza, właściwie od XIV w. nieustannie ulegając wpływom rady miejskiej, która ostatecznie w 1475 r. wykupiła wspomniany urząd. W każdym razie wpływ na obsadzenie tego stanowiska przez większość wieków średnich mieli rajcy, ale chyba przez cały ten czas nie wyklarował się nawet przybliżony termin wyboru nowego wójta. Należy więc założyć, że swoje przyrzeczenie składał on najpierw w chwili obejmowania stanowiska, a następnie rokrocznie powtarzał je na początku każdego roku.

Wspomniane wcześniej zapisy w księgach ławniczych świadczą natomiast o tym, że sędziowie tworzący ławę miejską wybierani byli najczęściej latem, z reguły nie w niedzielę (w przeciwieństwie do rajców). Przy notach dotyczących ich wyboru nie ma informacji o tym, czy składali wówczas przysięgę. Można jednak założyć, że przed objęciem stanowiska ślubowanie było konieczne. Nie wiadomo, czy na początku roku ponownie, wraz z innymi ślubującymi, powtarzali rotę - skoro ich wyboru również dokonywano rokrocznie, trudno przypuszczać, aby w ciągu swojej rocznej kadencji składali ślubowanie dwukrotnie.

Odnośnie do tejże przysięgi również nie zachowała się żadna relacja, na podstawie której można by odtworzyć ryt tego wydarzenia. Można założyć, że wyglądało to podobnie do składania przysięgi sądowej. Wszak każde iuramentum pozostawało w sferze sacrum i wymagało paramentów w postaci krucyfiksu czy Ewangelii. Temat rytuału przysięgi sądowej był już licznie podejmowany w wymienianej wcześniej literaturze; dość podsumować, że w każdym regionie mogło wyglądać to bardzo różnie. Przypominając relację złożenia przysięgi przez społeczność miejską nowo narodzonemu synowi króla Władysława Jagiełły i Zofii Holszańskiej, warto wspomnieć, że biskup Zbigniew Oleśnicki trzymał krzyż, na który ślubowali krakowianie. Naturalnie, homagium to miało inny charakter niż przysięga inaugurująca władzę np. rajców, jakkolwiek w Krakowie paramentem, na jaki przysięgano, niewątpliwie był właśnie krucyfiks ${ }^{57}$, na co zwracała uwagę

${ }^{57}$ Krucyfiks sądowy o wysokich walorach artystycznych zachował się na przykład w Toruniu, zob. W. Maisel, Archeologia prawna Polski, Poznań - Warszawa 1982, s. 167-168; J. Raczkowski, Tak zwany krzyż sadowy z ratusza toruńskiego na tle wyposażenia sal sądowych $w$ średniowieczu, „Rocznik Toruński”, 31, 2004, s. 27-63 (tam również dalsza literatura dotycząca krzyży w średniowiecznych ratuszach miejskich). 
już Bożena Wyrozumska, przywołując zapis z 1395 r. poświadczający zapłatę Jakubowi malarzowi za wykonanie krzyża super quo iuratur ${ }^{58}$. Według tej badaczki miał on się znajdować w sali sądowej ${ }^{59}$

Odnośnie do „miejskiej” przysięgi sądowej warto odnotować, że moment składania przysięgi przez mieszczanina uwieczniono na gdańskiej Tablicy Dziesięciorga Przykazań powstałej w ostatnim dziesięcioleciu XV w. Scena ta, ukazująca sąd mieszczan, ilustruje drugie przykazanie. Mieszczanin w obecności sędziego zasiadającego pod baldachimem oraz urzędnika sądowego, który przyjmuje przysięgę, klęczy, składając iuramentum na krzyż i ewangeliarz; niewykluczone, że oskarżony krzywoprzysięga ${ }^{60}$. Z kolei Michalina Duda i Sławomir Jóźwiak zwrócili uwagę na zapis w elbląskiej księdze rachunkowej, w której pod 1407 r. odnotowano zakup płótna, które von den heilgen wieszano podczas składania przysiąg sądowych"

W kontekście samego ceremoniału można domniemywać, że omawiany wyżej Kodeks Behema - jako księga niezwykle istotna w środowisku krakowskiej kancelarii, reprezentacyjna, będąca prawdopodobnie swoistym insygnium miejskim - był obecny podczas ślubowania i towarzyszył niejako inauguracji władzy, zwłaszcza rajców. Wiadomo wszakże, że w niektórych miastach przy składaniu przysięgi posługiwano się tablicami zawierającymi roty przysiąg ${ }^{62}$. Kodeks Behema mógł więc uświetniać na przykład wybory rady, które były bardzo doniosłym wydarzeniem $^{63}$, jakkolwiek trudno zgodzić się z tezą Leonarda Lepszego i Zofii Ameisenowej, jakoby na miniaturę Ukrzyżowanie składano przysięgi miejskie ${ }^{64}$.

${ }_{58}$ Najstarsze księgi II, s. 309.

59 B. Wyrozumska, Kancelaria, s. 44.

${ }^{60}$ Omówienie zabytku zob. A.S. Labuda, Cnota i grzech w gdańskiej tablicy dziesięciorga przykazań, czyli jak rzeczywistość przedstawienia obrazowego s(po)tyka się z rzeczywistościa miasta późnośredniowiecznego, „Artium Quaestiones” 7 (1995), s. 65-102, zwł. 86-88 (tam również przykłady podobnych przedstawień). Dokładna reprodukcja dzieła dostępna online: http://culture.pl/pl/ galeria/tablice-dziesieciorga-przykazan-detale-dziela-galeria [dostęp: 15.03.2016]. Ponadto zob. też B. Wyrozumska, Obyczaj średniowiecznej sali sądowej, passim.

${ }_{61}$ Nowa księga rachunkowa Starego Miasta Elblaga 1404-1414, cz. I: (1404-1410), wyd. M. Pelech, Warszawa-Poznań-Torun 1987, s. 83 (cyt. za: M. Duda, S. Jóźwiak, Sposoby sktadania przysięgi w państwie zakonu krzyżackiego $w$ Prusach $\mathrm{w}$ późnym średniowieczu - zarys problematyki, „Zapiski Historyczne” 79 (2014), z. 1, s. 9). Autorzy próbowali również zdefiniować pojęcie heiligen w kontekście paramentów towarzyszących składaniu przysiąg.

${ }_{62}$ W. Maisel, op. cit., s. 167-168.

${ }^{63}$ Z. Noga, op. cit., s. 23-26. Ponadto, jak już wspominano, ceremoniał wyboru władz miejskich w państwach europejskich został szeroko opisany przez niemieckiego historyka Dietricha W. Poecka: idem, op. cit.; idem, Zahl, Tag und Stuhl. Zur Semiotik der Ratswahl, „Frühmittelalterliche Studien" 33 (1999), s. 396-407.

${ }^{64}$ L. Lepszy, Studya nad ornamentyka kodeksów miniaturowych polskich, „Przemysł Artystyczny” 1 (1896), s. 6; Z. Ameisenowa, Codex Picturatus Baltazara Behema, „Sztuki Piękne” 1 (1924-1925), s. 537. 
Dalece wątpliwe jest, aby wizerunek krzyża w postaci malowidła książkowego zastąpił krucyfiks sam w sobie, jeśli był on stałym paramentem towarzyszącym uroczystości ślubowania. Uwagę na to zwrócił już Karol Estreicher, konkludując, iż: „Wydaje się, że jedynym celem, dla którego wlepiono miniaturę do kodeksu, była chęć podniesienia wartości i znaczenia księgi. Podobnie w kodeksie 170a Bibl. Jag. (prawo magdeburskie), domalowano w XVII w. minjaturę «Ukrzyżowania»" ${ }^{2}$. Zresztą, jak wspomniano, w krakowskiej kancelarii przechowywano krzyż, na który składano przysięgi.

Konkludując, należy zaznaczyć, że powyższe rozważania miały na celu wskazanie roli i funkcji przysięgi inaugurującej władzę wśród społeczeństwa miejskiego - nie tylko rady, ławy czy wójta, ale także wśród pomniejszych pracowników miejskich i rzemieślników. Roty przysiąg zachowanie w krakowskich kopiariuszach, w Kodeksie Grabowskiego i w Kodeksie Behema, są liczne i o ile zasób zachowany $\mathrm{w}$ pierwszym $\mathrm{z}$ wymienionych kopiarzy pozwala śledzić ewolucję treści - jak się okazuje tylko nieznaczną - o tyle nowa księga odsłania, jak się zdaje, realia funkcjonowania władzy w mieście. Przede wszystkim struktura rozmieszczenia treści przysiąg w kodeksie z początku XVI w. wskazuje na znaczną pozycję pisarza miejskiego, którego treść zaprzysiężenia znalazła się zaraz za rotą wypowiadaną przez rajców. Jak wykazano, to notarius civitatis był urzędnikiem najbardziej zbliżonym do rady, nie ławnicy, którzy formalnie zajmowali drugie miejsce w hierarchii instytucjonalnej miasta; ci skupieni byli raczej na sprawach wewnątrzmiejskich, podczas gdy skryba spełniał funkcję swoistego sekretarza realizującego politykę wewnętrzną i zewnętrzną rajców. Paradoksalnie jednak to ława miejska była kuźnią późniejszych członków rady.

Dodatkowo terminy i forma zaprzysiężenia podkreślały to, że rada miejska znajdowała się w centrum polityki miasta i to na niej opierało się funkcjonowanie ośrodka - przysięgę składali podczas bardzo uroczystej ceremonii, przysięgając sumienne wykonywanie obowiązków tylko przed władcą i innymi rajcami, co znacznie uwypukla ich autonomię i ekskluzywizm względem mieszczan niższych rangą i statusem społecznym oraz zaznacza wymowę ideową wydarzenia. Odbywanie wyborów innych urzędników, pomniejszych pracowników miejskich oraz starszych cechów w różnych terminach, często niekonsekwentnie i zapewne nie tak uroczyście, dodatkowo zaznacza podrzędność innych instytucji. Wybory te odbywały się jednak stosunkowo regularnie, co wskazuje na przykładanie niezwykłej wagi do tychże ślubowań. Wszakże wiadomo, że te same osoby bardzo często pełniły swoje funkcje nieprzerwanie wiele lat, jednak - według wpisów w księgach miejskich - konieczne było, aby rokrocznie

${ }^{65}$ K. Estreicher, Miniatury Kodeksu Bema oraz ich treść obyczajowa, „Rocznik Krakowski” 24 (1933), s. 237, przyp. 1. 
odnowić swoje przyrzeczenie. O randze przysięgi w mieście średniowiecznym świadczą także omówione wyżej homagia składane władcom oraz liczne zmiany, zazwyczaj jedynie kosmetyczne, które można śledzić poprzez analizę rot w I kodyfikacji krakowskiej. Te ostatnie wyraźnie wskazują, że treść przysięgi nie była bez znaczenia.

\section{IURAMENTUM AT THE INAUGURATION OF THE AUTHORITIES IN A MEDIEVAL TOWN ON THE EXAMPLE OF CRACOW}

\section{Summary}

The article is devoted to the oaths related to the inauguration of the authorities in medieval Cracow. The paper is mainly based on Cracow's two municipal codes: the Grabowski Codex (from the $14^{\text {th }}$ and the $15^{\text {th }}$ century) and the Balthasar Behem Codex (from the beginning of the $16^{\text {th }}$ century).

The oath played an enormous part in the legal and social relations in the Old Polish period. Cracow's burghers took an oath of homage (Latin homagium) to every single Polish monarch. Moreover, the clerks, municipal workers and craftsmen yearly pledged their allegiance to the city and took a vow to diligently perform their professional duties. The Grabowski Codex contains oaths (Latin iuramenta) which were written down chaotically for about two centuries. Consequently, it allows one to follow even minor changes in the content of the vows which highlights the significance of the contents of the oath themselves. On the other hand, the Balthasar Behem Code, which was a dignified book and a municipal insignia (Latin insignium), gathered the contemporary oaths in an orderly fashion. As a consequence, it outlines the hierarchy of the municipal clerks and institutions. This further emphasizes the huge importance of a municipal scribe whose oath is inscribed right after the pledge of the town council which was the main municipal institution in town.

This paper also undertakes the topic of the elections of new people to perform various functions, pinpoints the dates of these nominations and it outlines the issue of the ceremonies which accompany them. At the same time, it emphasizes the splendour connected with the election of new members of the city council.

\section{IURAMENTUM POUR L'INAUGURATION D'UN NOUVEAU GOUVERNEMENT DANS UNE CITÉ MÉDIÉVALE SUR L’EXEMPLE DE CRACOVIE}

\section{Résumé}

L'article traite des serments accompagnant l'inauguration d'un gouvernement à Cracovie médiévale. Les sources principales pour l'analyse de cette question étaient deux cartulaires de la ville: le Code Grabowski du XIV et XVe siècles et le Code Behem du 
début du $\mathrm{XVI}^{\mathrm{e}}$ siècle. Le serment jouait un rôle important dans les relations juridiques et sociales de l'ancienne Pologne. Les bourgeois de Cracovie faisaient un serment homagial aux souverains successifs du Royaume de Pologne, par contre, les fonctionnaires, les officiers municipaux et les artisans prêtaient serment de fidélité à la ville et promettaient d'accomplir consciencieusement leurs devoirs.

Le Code Grabowski contient des iuramenta inscrits de manière chaotique pendant environ 200 ans, de sorte qu'il permet de suivre même de légères modifications dans les textes des serments, indiquant la grande importance qu'on attachait au texte du serment lui-même. Par contre, le Code Behem, étant un livre digne, constituait un insigne de la ville, recueillait les serments actuels de manière ordonnée, soulignant ainsi la hiérarchie des fonctionnaires et des institutions municipales, soulignant la grande importance de l'écrivain municipal dont le serment est entré dans le registre immédiatement après le serment du conseil municipal, l'institution la plus importante de la ville. Le texte s'occupe également des élections de nouvelles personnes pour des postes spécifiques, indique les dates de ces nominations et attire l'attention sur des célébrations qui les accompagnaient, en soulignant la splendeur liée à l'élection de nouveaux membres du conseil municipal. 